\title{
INFLUENCE OF CREDIT RATINGS ON BANK SOUNDNESS. RUSSIAN ASPECT
}

\author{
Myznikova Tatyana \\ South Ural State University \\ Chelyabinsk, Russia \\ miz108410098@mail.ru
}

\author{
Zhdanova Nina \\ South Ural State University \\ Chelyabinsk, Russia \\ NinaVik-691@mail.ru
}

\author{
Bunova Elena \\ South Ural State University \\ Chelyabinsk, Russia \\ albv70@mail.ru
}

\begin{abstract}
This research analyzes the influence of credit ratings on the soundness of the Russian banks. The research logic is presented in the following way. The introduction gives a review of previous scientific publications on ratings. The following part shows a review of the rating activity in the Russian banking sector over the period from 2009 till 2016. Ratings of three international and four national rating agencies have been taken into consideration. The authors conclude that ratings do not considerably influence the soundness of the rated bank and the banking system in general and names reasons for this phenomenon. The research findings can be used by banks for risk and financial regulators management.
\end{abstract}

Keywords - credit rating, credit rating agencies, rating field, financial market regulators, national rating system, soundness of the banking system

\section{INTRODUCTION}

Credit rating is a special tool reflecting the credit agency's opinion on the issuer's credit worthiness and the risk level of its debt liabilities.

It is widely accepted that credit rating agencies have a profound influence on capital markets. Acting as information intermediaries, focusing on evaluation of organizations, rating agencies enable financial markets to operate efficiently.

Issuers, investors and regulators use ratings to make investment decisions, develop their own analytical risk management systems, adopt regulatory documents and requirements to the capital market players.

As applied to banks, credit rating characterizes the organization's ability and, what is more important, its readiness to serve its debts.

Bank ratings have become most widespread in Russia. It is explained by a high risk of transactions on the Russian financial markets, a relative transparency of banker books as compared to enterprise accounting and strict requirements to banker books on the part of prudential supervisory authorities.

However, credit ratings can considerably influence the activity of individual banks and the national banking system in general.

In view of the fact that the global financial crisis identified multiple defects in the rating system, the issue of ratings' importance for the Russian banks has become crucial.
The financial market and its key segment - banking sector, are systematically exposed to changes. It is preconditioned, firstly, by the derivative laws requiring continuous development and improvement and, secondly, by the external environmental factors - economic and political conditions, in which it functions. Soundness of banks is ensured not only by their management professionalism, but also by the efficiency of the performed operations and the role of the state in regulation of the banking sector. Rating agencies, which ratings are used by potential bank clients, also considerably influence soundness of banks. In this connection, as practical experience shows, different agencies can give different rating scores, thus, misleading potential users about this information. Besides, the problem of the rating quality is also controversial [1].

It is not infrequent when a positive rating of a rating agency does not save a bank from revoking its license for the violations revealed in management or a failure to observe the regulations.

Thus, topicality of the formalized evidential base of the influence of rating agencies on the bank performance is unconditional and welltimed.

The scholarly importance of the issue under consideration is confirmed by an extensive discussion in the financial circles.

Systematic researches dealing with credit ratings have appeared since the second half of the 90s. The majority of researchers of this period make different arguments to justify efficiency of credit ratings giving a rational credit rating of the borrower. Most active developers of the rating theory are Altman, I. Altman Edward I. [2]; Allen, F. Allen Franklin [3]; Cantor, R and Packer, F. Cantor Richard, Packer Frank [4, 6]; Lee, S.H. Lee Sukhun [5]

Many works deal with the comparative analysis of ratings and rating scales. Among them, there are Cantor Richard, Packer Frank [6]; Frydman Halina [7], Schuermann Til [7]; Gaillard Norbert [8]; Koopman Sien Jan, Lucas Andre, Monteiro Andre B. [9]. There are also studying approaches to analysis and modeling of ratings: Trueck Stefan, Svetlozar Rachev R. [10]; Pederzoli Chiara, Thoma Grid, Torricelli Costanza [11]; Doumpos Michail, Pasiouras Fotios [12].

The influence of rating changes on creditworthiness was considered by Altman, I. and Rijken H. Altman Edward I, Rijken Herbert A. [13], Kiesel, F., Schiereck, D. Kiesel Florian, Schiereck Dirk [14]; Manso Gustavo [15] et al.

The surge in theoretical and empirical studies covering this subject is connected with the crisis of 2008. There is a simultaneous 
burst of the transformation speed in the rating field. Basic changes are connected with strengthening of the regulatory influence on the activity of credit rating agencies. It is explained by imperfection of the existing global rating system. The authors, whose works describe failures of ratings, include Dimitrov Valentin, Palia Darius N., Tang Leo [16]; Stolper Anno [17]; Becker Bo, Milbourn Todd T. [18]; Fulghieri Paolo, Strobl Günter, Xia Han [19].

A biased approach and a brighter political overtone in assessment on the part of international rating agencies are mentioned in many researches. One of the latest works dealing with this issue is a vast research of Belgium scientists Luitel Prabesh, Vanpée Rosanne, De Moor Lieven [20].

For the purposes of this research, the issue on the influence of national factors on ratings and their consequences for soundness of banks is of importance. Over the last years, a wide range of studies has identified a diverse influence of ratings on banks in developed and developing economies. A differentiated influence of the rating on soundness of issuers of different quality is explained by characteristics of the issuer's region [22].

Several works of Russian researcher A.M. Karminsky deal with the issue of influence of credit ratings on the performance of banks from the CIS countries, including Russian banks [23, 24].

However, the issue concerning the importance of influence of ratings on soundness of both individual banks and the banking system in general remains pending.

For the Russian financial market currently functioning in the conditions of active constraints, the issue of an efficient rating system is most topical.

\section{MATERIALS AND METHODS}

In consideration of the aforesaid opinions, let us assume that rating does not have a considerable influence on financial performance of credit organizations. It is confirmed by the analysis of the rating services market and ratings of Russian banks, making up the general classifier of ratings and then - the correlation analysis of the dependence between ratings and key financial indicators of banks. There are the following model building stages:

Stage 1 - Analysis of the rating services market and ratings of Russian banks.

The Russian rating services market is represented by 7 rating agencies. These are branches and representative offices of international rating agencies Fitch Ratings, Standard \& Poor's and Moody's Investors Service. Russian rating agencies include Expert RA, Rus-Rating, National Rating Agency and AK\&M. The share of rating agencies on the Russian market in 2014 and 2016 is shown in figure 1 .

It should be noted that over the last several years, the market share of foreign rating agencies has decreased. In 2014, $29 \%$ of the Russian rating services market fell in international agencies, while in 2016, their share comprised $27 \%$. Thus, the share of international RA reduced by $2 \%$.
Share of rating agencies in the rating market of Russia $(\%)$

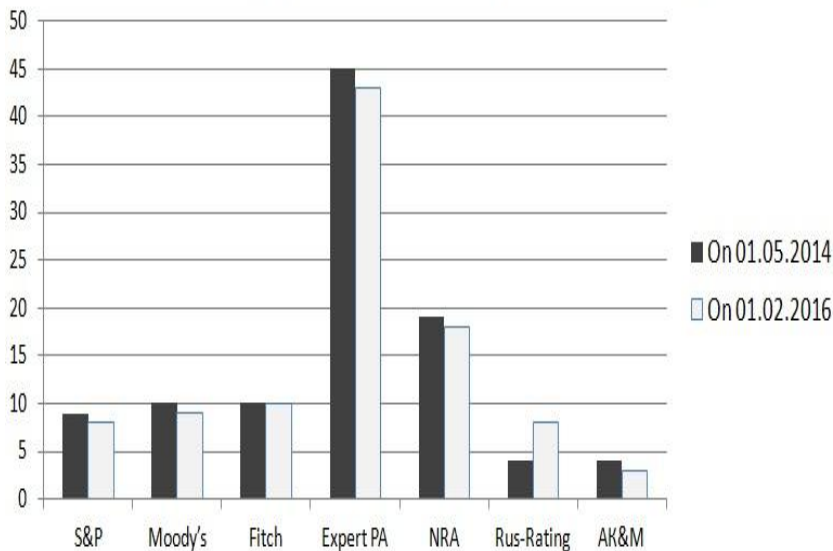

Fig. 1. Share of rating agencies in the Russian rating market, in percentage terms

Let us outline the factors, which influenced the reduction of the share. They are:

- depletion of the market growth potential (all the major banks, having access to the international market, have already been rated by international rating agencies);

- high price of the services (the cost of obtaining a foreign rating is higher than that of national rating agencies);

It should be noted that the rating market is oligopolistic, which is confirmed by several factors:

1. The market is highly concentrated. The Herfindahl-Hirschman index comprises 2491 , which is higher than 1800 . This value allows concluding that the rating services market refers to highlyconcentrated markets, and, consequently, it is low competitive.

2. The market concentration allows conventional competitors to avoid a deep involvement in the process of studying the activity of the rated party.

3. There are no truly good substitutions for credit ratings

4. There are regulatory (regulators require credit ratings from rating agencies, so that the rated party could access certain operations) and natural barriers of entry into the market (major rating agencies occupy the largest part of the market; new and small rating agencies have less financial resources and cannot compete from the perspective of their professional talent).

Then, the authors analyzed banks rated by the national and international rating agencies, which allowed identifying the following tendencies.

Over the last 6 years, the number of assigned ratings increased 2 times. It should be noted that about $30 \%$ of all the assigned credit ratings fall to banks. 


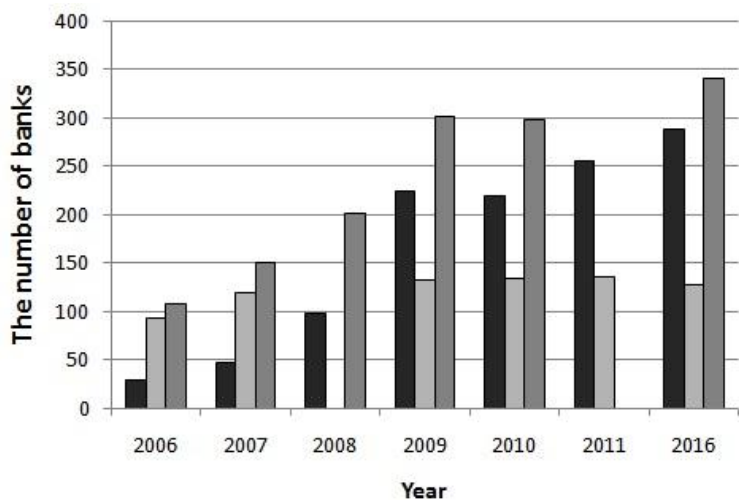

口Internation aTotal

Fig. 2. Number of rated banks

According to figure 2, over 10 years, the total number of banks rated by the rating agencies has significantly increased (the growth comprised $321 \%$ ). In general, there is an upward dynamics by the number of banks rated by both Russian and international rating agencies. A sharp increase in the number of rated banks is preconditioned by the growing activity of the Russian agencies.

To date, 288 Russian banks are rated by the Russian rating agencies (RA) and 128 banks - by the international RA. At the same time, several banks are rated by several agencies (table 4 ).

TABLE I. NUMBER OF BANKS RATED BY SEVERAL RA

\begin{tabular}{|l|r|}
\hline \multicolumn{1}{|c|}{ Rating agencies } & Number of banks \\
\hline Moody's + Fitch & 19 \\
\hline S\&P + Fitch & 6 \\
\hline Moody's + S\&P & 12 \\
\hline S\&P + Moody's + Fitch & 6 \\
\hline Expert RA + NRA & 15 \\
\hline Expert RA + Rus-Rating & 11 \\
\hline NRA + Rus-Rating & 7 \\
\hline Rus-Rating + AK\&M & 1 \\
\hline
\end{tabular}

Thus, the Russian rating space has been forming rather dynamically. The number of rated banks has increased 3.2 times. A sharp increase in the number of rated banks is preconditioned by the increased activity of the Russian agencies. Their share by the number of rated banks has comprised $84.4 \%$.

\section{Stage 2 - Making up the general classifier of ratings.}

It is beyond argument that the Russian RA and the agencies rating banks on international scales, in accordance with Basel II, put their own influence in the expert rating which sometimes considerably differs from the rating of other states.

In the rating, made by the national scale, issuers are ranked by the risk level in this country. Macroeconomic factors are considered to the extent that they influence individual features of every issuer in comparison to other issuers in Russia. The international scale works in a different manner - via cross-country comparisons.

In this research, in order to formalize achievement of the results and to provide for its mathematical proof, ratings are united into 5 groups: from 1 to 5 , where:

1 - the worst value - unsatisfactory level of the financial standing;

2 - low level of the bank's financial standing;

3 - satisfactory level;

4 - high level;
5 - premium level of creditworthiness.

TABLE II. COMPLIANCE OF THE RATING SCALES OF THE RUSSIAN BANKS

\begin{tabular}{|c|c|c|c|c|c|c|}
\hline \multicolumn{3}{|c|}{$\begin{array}{c}\text { International scale } \\
\text { (according to Basel II) } \\
\text { (classified by the authors } \\
\text { rating scale) }\end{array}$} & \multicolumn{4}{|c|}{$\begin{array}{l}\text { Russian scales of the rating agencies } \\
\text { registered in the RF Ministry of Finance } \\
\text { (classified by the authors' rating scale) }\end{array}$} \\
\hline Moody's & $\mathrm{S} \& \mathrm{P}$ & Fitch & $\mathrm{AK} \& \mathrm{M}$ & $\begin{array}{c}\text { Expert } \\
\text { RA }\end{array}$ & NRA & $\begin{array}{l}\text { Rus- } \\
\text { Rating }\end{array}$ \\
\hline A3 (5) & $A-(5)$ & $A-(5)$ & & & & \\
\hline Baal (5) & $\mathrm{BBB}+(5)$ & $\mathrm{BBB}+(5)$ & & & & \\
\hline Baa2 (5) & BBB (5) & $\mathrm{BBB}(5)$ & \multirow{4}{*}{$\mathrm{A}++(5)$} & \multirow{4}{*}{$\mathrm{A}++(5)$} & \multirow{4}{*}{ AAA (5) } & \\
\hline $\mathrm{Baa} 3$ (5) & $\mathrm{BBB}-(5)$ & $\mathrm{BBB}-(5)$ & & & & $\mathrm{A}+(5)$ \\
\hline Ba1 (5) & $\mathrm{BB}+(5)$ & $\mathrm{BB}+(5)$ & & & & A (5) \\
\hline $\mathrm{Ba} 2$ (4) & & & & & & $\mathrm{A}-(4)$ \\
\hline Ba3 (4) & BB- (4) & BB- (4) & \multirow{3}{*}{$\mathrm{A}+(4)$} & \multirow{2}{*}{$A+(4)$} & $\mathrm{AA}+(4)$ & \\
\hline B1 (4) & $\mathrm{B}+(4)$ & $\mathrm{B}+(4)$ & & & $\mathrm{AA}(4)$ & BBB-(4) \\
\hline \multirow[t]{2}{*}{ B2 (3) } & \multirow{2}{*}{ B (3) } & \multirow{2}{*}{ B (3) } & & \multirow{3}{*}{ A (3) } & \multirow{2}{*}{ A- (3) } & $\mathrm{BB}+(3)$ \\
\hline & & & \multirow{3}{*}{ A (3) } & & & \\
\hline \multirow[t]{2}{*}{ B3 (3) } & \multirow{2}{*}{ B- (3) } & \multirow{2}{*}{$\mathrm{B}-(3)$} & & & $\mathrm{A}+(3)$ & \\
\hline & & & & \multirow{3}{*}{$\mathrm{B}++(3)$} & A (3) & BB-(3) \\
\hline \multirow[t]{2}{*}{ Caal (2) } & \multirow{2}{*}{$\mathrm{CCC}+(2)$} & \multirow{6}{*}{ CCC (2) } & \multirow{4}{*}{$\mathrm{B}++(2)$} & & A- (3) & \\
\hline & & & & & $\mathrm{BBB}+(3)$ & (I) (J) \\
\hline \multirow[t]{2}{*}{$\mathrm{Caa} 2(2)$} & \multirow{2}{*}{ CCC (2) } & & & \multirow{2}{*}{$\mathrm{B}+(2)$} & $\begin{array}{c}\mathrm{BBB}(2) \\
\mathrm{BBB}-\end{array}$ & B (2) \\
\hline & & & & & $\mathrm{BB}+$ & $\mathrm{B}-(2)$ \\
\hline \multirow[t]{2}{*}{$\mathrm{Caa} 3(1)$} & \multirow{2}{*}{$\mathrm{CCC}-(1)$} & & \multirow{2}{*}{$\mathrm{B}+(1)$} & \multirow{2}{*}{ B (1) } & BB (1) & $\mathrm{CCC}+(1)$ \\
\hline & & & & & BB- & CCC (1) \\
\hline
\end{tabular}

Stage 3 - Mathematical modeling and carrying out the correlation analysis, correlating the rating and the bank's financial performance indicator.

\section{RESULTS}

In order to make a mathematical relationship, which allows answering the main question of this research: whether ratings, made by the rating agencies, influence financial indicators of the bank, let us choose the most significant, in the authors' opinion, performance 
indicators of banks. Banks, which have published their statements in open public information sources, have been chosen for analysis. The authors have analyzed statements of the banks, having a critical system importance. That is, a default of such banks can result in a system crisis in the majority of segments of the financial market, which will considerably affect the financial solvency and the state of the national economy in general. These are, in particular: Alfa Bank OJSC, Sberbank of Russia PJSC, BANK VTB (PJSC), Russian Agricultural Bank JSC, Gazprombank (Joint-Stock Company), Rosbank PJSC, Financial Corporation Bank Otkritie PJSC, Promsvyazbank PJSC. Their ratings over the period of $2009-2016$ are mainly at the level of soundness class $5-4$ according to the authors' scale.

The analysis is also based on the open, available statements of banks with less stable indicators: Bank Saint-Petersburg PJSC, Sovkombank PJSC, Ural Bank of Reconstruction and Development PJSC, Trust National Bank OJSC, Citibank Commercial Bank JSC, Bank Russian Standard JSC, Svyaz-Bank Joint-Stock Commercial Bank PJSC, Absolutbank Joint-Stock Commercial Bank, MTS-Bank PJSC, Bank Vozrozhdenie (PJSC).

Besides, banks of the second tier have been also rated in some periods.

Thus, 18 major credit organizations took part in the research.

Indicators characterizing performance of the above-mentioned banks in the dynamics over a series of years constitute the following analysis elements:

\section{$\mathrm{X} 1$ - net interest yields (negative interest margin);}

$\mathrm{X} 2$ - change of the reserve for possible bad debts, losses from outstanding and equivalent loans, funds placed on correspondent accounts, as well as accrued interest yields;

X3 - net interest yields (negative interest margin) after creation of the reserve for possible losses;

$\mathrm{X} 4$ - net income from operations with financial assets measured at the fair value through profit or loss;

$$
\begin{aligned}
& \text { X5 - other legal entities' equity income; } \\
& \text { X6 - net profit (losses); } \\
& \text { X7 - operating expenses; } \\
& \text { X8 - pretax profit (loss); } \\
& \text { X9 - posttax profit (loss); } \\
& \text { X10 - outstanding profit (loss) over the accounting period. }
\end{aligned}
$$

The authors' selection of elements for analysis is preconditioned by the fact that, in the authors' opinion, the rating could influence the opinion of the bank's partners choosing a credit organization, which, in its turn, could influence its performance.

In the research, the correlation analysis is used for data analysis. This statistical data processing method is mainstream in the economy. The authors refused from the popular and frequently used Pearson correlation coefficient, also called "linear correlation", as it allows one to measure the degree of linear relationship between variables, which undoubtedly limits the ability to use this correlation coefficient to solve problems of analyzing the influence of the "Agencies' overall rating" on the bank's performance indicators. Besides, it can be applied to the condition of a normal distribution of the collative variables. At the same time, if at least one of the two variables has an ordinal scale or is not normally distributed, it is expedient to use the Spearsman or Kendall rank correlation applied in this research as more accurate methods to define correlation.
In order to estimate the influence of the "Agencies' overall rating" on the bank's performance indicators, let us calculate the Spearsman coefficient by the following formula (1):

$$
\mathrm{R}_{\mathrm{x} / \mathrm{y}}=1-\frac{6 \sum d_{i}^{2}}{n\left(n^{2}-1\right)},
$$

where $d^{2} i$ - squared difference of ranks;

$n$-number of observations (number of pairs of ranks).

There is calculation of the Spearsman rank correlation coefficient between the "Agencies" overall rating" and "Net interest yields (negative interest margin)" ( $\mathrm{R}=0.56)$, as well as between the "Agencies' overall rating" and "Other legal entities' equity income" $(\mathrm{R}=0.481)$.

In order to check and to confirm the obtained results, the authors calculated the Kendall coefficient (concordance coefficient) by the following formula (2):

$$
\tau=\frac{4 R}{n(n-1)}-1
$$

where $R$ - sum total of the ranks;

$n$ - number of observations.

Calculation of the Kendall rank correlation coefficient between variables "Agencies' overall rating" and the bank's performance indicators also allowed one to identify a slight relationship between variables "Agencies' overall rating" and "Net interest yields (negative interest margin)" ( $\mathrm{R}=0.42)$, as well as between indicators "Agencies' overall rating" and "Other legal entities' equity income" $(\mathrm{R}=0.37)$.

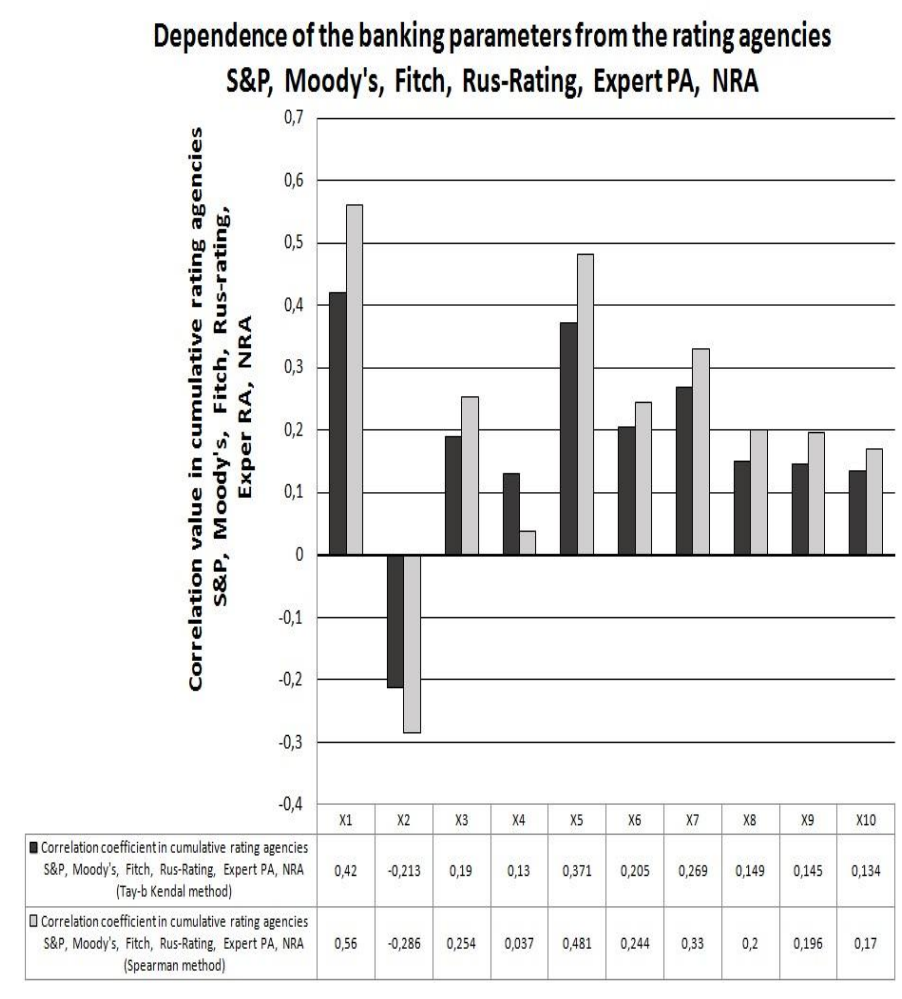

Fig. 3. Correlation dependence between the rating agency's rating and the bank's financial indicators 
The values of the Kendall coefficient confirm the conclusions on presence of a positive statistically important relationship between the "Agencies' overall rating" and "Net interest yields (negative interest margin)" and "Other legal entities' equity income". The analysis results are summarized and graphically shown in figure 3.

The Kendall coefficient is more "appropriate", as it analyzes the relationship between the variables deeper and in more detail, sorting all possible matches between pairs of values. The Spearsman coefficient considers the quantitative correlation degree between the variables better.

\section{CONCLUSIONS}

Monitoring the scholarly literature, covering researches and analysis of the importance of the influence of ratings, assigned by rating agencies on the financial performance indicators of banks with different creditworthiness, allowed one to form a more accurate, in the author's opinion, statement that there is a certain relationship between ratings. In this regard, the authors identified a relationship among the agency's rating and such indicators as "Net interest yields (NIY) (negative interest margin)" and "Other legal entities' equity income". Considering that NIY is one of the key indicators reflecting effectiveness of active bank operations, one can suggest that the rating of a rating agency will have a certain influence on the potential counterparty's decision on cooperation with the bank. The second indicator - "Other legal entities' equity income", correlating with the "Agencies' overall rating", also confirms the conclusions made.

At the same time, the remaining 8 indicators, which are no less important for the bank's financial soundness, do not allow one to make any highly accurate conclusions about the level of influence of ratings, assigned by the rating agencies, on the banks' performance.

Absence of a considerable influence of the credit rating on performance indicators of the Russian banks can be explained by the following factors:

- availability of the national deposit insurance system, which considerably simplifies the process of choosing a credit organization, allowing depositors - private individuals and self-employed entrepreneurs - not to pay attention to soundness and, consequently, to the bank's ratings;

- lack of knowledge - not only private investors but also regulators do not fully understand the meaning of credit rating;

- banks interested in a high rating pay for ratings. It results in the lack of trust, whereas ratings do not often reflect the actual situation. The agency's rating does not guarantee soundness (credit quality) of the organization or, vice versa, a forecast of a default under its liabilities. It is just an opinion about a relative creditworthiness of a bank according to a certain scale, which allows comparing levels of credit risks of different organizations. For example, according to Standard\&Poor's, the credit quality of Alfa-Bank is higher (BB/Negative/B) than that of Binbank (B/Negative/B). However, neither rating gives a $100 \%$ guarantee of the issuer's soundness. They just mean that the probability of a default under liabilities of Alfa-Bank is lower than that on Binbank.

\section{References}

[1] T. Myznikova, Features of functioning of credit system of Russia in conditions of globalization of the banking, collection: SCIENCE SUSU materials of the 66th scientific conference (Electronic resource). The Ministry of education and science of the Russian Federation, South Ural state University; responsible for release: Vaulin S. D, 2014, pp. 9991004].

[2] E.I. Altman, The importance and subtlety of credit rating migration (1998) Journal of Banking and Finance, 22 (10-11), pp. 1231-1247.

[3] F. Allen, The market for information and the origin of financial intermediation, Journal of Financial Intermediation, 1 (1), pp. 3-30, 1990.

[4] R. Cantor, An introduction to recent research on credit ratings, Journal of Banking and Finance, 28 (11), pp. 2565-2573, 2004.

[5] S.H. Lee, Are the credit ratings assigned by bankers based on the willingness of LDC borrowers to repay? Journal of Development Economics, 40 (2), pp. 349-359, 1993.

[6] R. Cantor, F. Packer, Differences of opinion and selection bias in the credit rating industry, Journal of Banking and Finance, 21 (10), pp. 1395-1417, 1997

[7] H. Frydman, T. Schuermann, Credit rating dynamics and Markov mixture models, Journal of Banking and Finance, 32 (6), pp. 1062-1075, 2008

[8] N. A. Gaillard, Century of sovereign ratings, A Century of Sovereign Ratings, 9781461405238, pp. 1-196, 2012.

[9] S.J. Koopman, A. Lucas, A. Monteiro, The multi-state latent factor intensity model for credit rating transitions, Journal of Econometrics, 142 (1), pp. 399-424, 2008.

[10] Trueck, S., Svetlozar, T.R. Rating Based Modeling of Credit Risk (2009) Rating Based Modeling of Credit Risk, 266 p.

[11] C. Pederzoli, G. Thoma, C. Torricelli, Modelling Credit Risk for Innovative SMEs: The Role of Innovation Measures, Journal of Financial Services Research, 44 (1), pp. 111-129, 2013.

[12] M. Doumpos, F. Pasiouras, Developing and testing models for replicating credit ratings: A multicriteria approach, Computational Economics, 25 (4), pp. 327-341, 2005.

[13] E.I. Altman, H.A. Rijken, How rating agencies achieve rating stability, ournal of Banking and Finance, 28 (11), pp. 2679-2714, 2004.

[14] F. Kiesel, D. Schiereck, The effect of ratings announcements, on firms in bank-based systems, Journal of Fixed Income, 24 (4), pp. 84-95, 2015

[15] G. Manso, Feedback effects of credit ratings, Journal of Financial Economics, 109 (2), pp. 535-548, 2013.

[16] V. Dimitrov, D. Palia, L. Tang, Impact of the Dodd-Frank act on credit ratings, Journal of Financial Economics, 115 (3), pp. 505-520, 2015.

[17] Stolper, A. Regulation of credit rating agencies, Journal of Banking and Finance, 33 (7), pp. 1266-1273, 2009.

[18] B. Becker, T. Milbourn, How did increased competition affect credit ratings? Journal of Financial Economics, 101 (3), pp. 493-514, 2011.

[19] P. Fulghieri, G. Strobl, H. Xia, The economics of solicited and unsolicited credit ratings, Review of Financial Studies, 27 (2), pp. 484518, 2014.

[20] P. Luitel, R. Vanpée, L. De Moor, Pernicious effects: How the credit rating agencies disadvantage emerging markets, Research in International Business and Finance, 38, pp. 286-298, 2016.

[21] G. Ferri, L.-G. Liu, G. Majnoni, The role of rating agency assessments in less developed countries: Impact of the proposed Basel guidelines, Journal of Banking and Finance, 25 (1), pp. 115-148, 2001

[22] G. Williams, R. Alsakka, O. Gwilym, Does sovereign creditworthiness affect bank valuations in emerging markets? Journal of International Financial Markets, Institutions and Money, 36, pp. 113-129, 2015.

[23] A. Karminsky, Models for the corporate credit ratings. Working Paper WP 2009/X R. Moscow, New Economic School, 2009.

[24] A.Karminsky, The synergy of rating agencies' efforts: Russian experience, Financial Econometrics and Empirical Market Microstructure, pp. 93-109, 2015. 